\title{
Characteristics of robust animals for grass-based production systems
}

\author{
L. Delaby ${ }^{1 \dagger}$, F. Buckley², N. McHugh², F. Blanc ${ }^{3}$ \\ 'INRAE, AgroCampus Ouest, UMR Physiologie, Environnement et Génétique pour l'Animal et les Systèmes d'Elevage, 35590 Saint Gilles \\ France \\ ${ }^{2}$ Teagasc, Animal \& Grassland Research and Innovation Centre, Moorepark, Fermoy, Co. Cork, Ireland \\ IINRAE, Université Clermont Auvergne, VetAgro Sup, UMR Herbivores, 63122 Saint-Genès-Champanelle, France
}

Abstract

A characterisation of dairy, beef and sheep breeds and/or strains best suited to profitable/sustainable production within the context of European [semi] intensive pasture-based systems is presented. To deliver optimal performance, pasture must be managed effectively, but pasture-based systems are less energy intensive, are climate sensitive and induce challenges and constraints not normally posed to animals in intensive feeding environments. This emphasises the importance of animal traits associated with robustness and adaptive abilities. A survey of French dairy farmers concluded that a robust cow is an "invisible" cow with a long lifetime. The traits common to both indoor and grazing systems include: efficient converters of feed to human edible products, functionality, being healthy, reproductively fit and exhibiting longevity. Unique to successful grazing is the capability to achieve large intakes of forage to meet productive potential, an ability to adapt to fluctuating feed supply and, in seasonal systems, the ability to conceive and give birth at the appropriate time each year, usually within $365 \mathrm{~d}$. The breed or strain of choice may differ based on local management constraints and objectives; however, general principles apply, and ideally should be guided by a suitable selection index combining all of the economically important traits appropriate to the local conditions and systems.

Keywords

Grass-based system $\bullet$ grazing $\cdot$ robustness $\cdot$ selection

\section{Introduction}

As a consequence of the increasing world demand for food associated with the growth of the human population, the future requires promotion of more efficient, sustainable livestock systems and also high-quality human food. Ruminant production systems have to make better use of forages, by-products and transform greater proportions of non-human competitive products into human edible products. In the context of this paper, pasture-based systems are characterised as systems where the primary feed source is grazed grass, typically $\geq 60 \%$ of the diet. The extent and efficiency with which grazed pasture is maximised can vary considerably. Intensified pasture-based systems such as those practiced in Ireland are characterised by long-term permanent pastures, the application of grazing management practices to maximise pasture production and quality in combination with relatively high stocking density to result in high milk solids or carcass production per unit area. Less-intensified pasture-based systems, more typical of France, tend to be associated with a more diverse environment, multispecies pastures, with legumes or natural grasslands, seasonal climatic extremes and availability of high-quality alternative feeds. Common, however, is a lower cost of production (O'Donovan \& Delaby, 2016) and environmental sustainability associated with the grassland ecosystem (Huguenin-Elie et al., 2018). A further advantage of pasture-based systems is greater societal acceptability or perception as a more "friendly livestock system" (Cardoso et al., 2016). But the advantages of grass-based systems are only effective if the characteristics of the dairy cattle, beef cattle or sheep are compatible with the demands and limits of the system.

The objective of this paper is to highlight such specificities and to outline the key animal characteristics required by robust cattle and sheep in pasture-based systems. 


\section{A brief background to grass-based system specificities}

In contrast to dairy cattle where only about $10 \%$ of the world's milk production is from grazing systems, beef and sheep are primarily managed under grazing. Consequently, in general, different strains of individual beef or sheep breeds have either not evolved from selection in different production environments, or they have not spread outside of their original geographical area (Buckley et al., 2005). Dairy cows that are optimal in a pasture-based system of production share many general characteristics with cows that are appropriate for a non-pasture system. However, the relative importance of traits can differ (Washburn \& Mullen, 2014). Nutrient demand intentionally coincides with seasonal forage availability, fertility is emphasised, and generally so is selection for high milk fat and protein content. Similar principles apply to beef and sheep where production is also chiefly based on the efficient conversion of grass to meat. As with seasonal pasture-based dairying, efficiency is optimised when beef cows/ewes give birth in spring with increasing herd/flock feed demand matched by increasing pasture supply. Pasture-based systems are generally more constraining, less stable and more uncertain than indoor-based systems, whereby the system is designed to serve the animal. In pasture-based systems the animal is faced with natural irregularities or antagonisms, such as climatic conditions, parasitic agents and so on. As the animal is de facto an integral part of the system, the animal is expected to contribute to its ability to face environmental variability and hazards. This is called robustness. Genetically robust dairy cows are less sensitive to sub-optimal circumstances (Veerkamp et al., 2013). Friggens et al. (2017) proposed a generic definition of animal robustness as "The ability, in the face of environmental constraints, to carry on doing the various things that the animal needs to do to favour its future ability to reproduce".

\section{Ability to adapt to grazing}

Maximising grass intake is a key characteristic of the most intensive grass-based dairy production systems (Delagarde et al., 2001). Feeding behaviour is inextricably linked to the nature of the feed on offer and the circumstance by which the feed is presented (Prendiville et al., 2010). Systems based on grazed pasture intrinsically limit nutrient intake compared with indoor total mixed ration (TMR) diets. This is evident from studies conducted in the United States by Kolver \& Muller (1998) who suggested a $20 \%$ decrease in daily intake with pasture-fed cows. Similar results were observed in Ireland by
Kennedy et al. (2003) and Horan et al. (2006) where Holstein cows which were highly selected for milk volume were not capable of eating enough to satisfy the demand associated with their milk production potential. Apart from environmental, plant and management factors (Dillon, 2005), milk production from pasture is limited by the ability of the grazing animal to consume sufficient quantities of herbage (Stakelum \& Dillon, 2003). Increased grass allowance induces higher levels of grass intake but also higher levels of refusals and leads to reduced pasture utilisation (Pérez-Prieto \& Delagarde, 2013; Delaby \& Horan, 2017). Therefore, a balance must be achieved between performance on a per-animal and per-hectare basis (McCarthy et al., 2011). Effective intensive pasture management enforces limited grass allowance, balancing the dual objectives of generous feeding to achieve performance and high levels of pasture utilisation, thus optimising farm profitability (Penno, 1998).

A study in beef cattle by Goodman et al. (2016) on rangeland pastures has observed behavioural adaptation to the reduction in pasture availability. Across two diverse temperament profiles, beef cows classified as fast eaters when indoors were shown to spend less time close to the drinker and to explore a larger area of the pasture at grazing. They were considered to express a "go-getters" temperament. In contrast, slow eaters expressed a "laid-back" temperament. Interestingly, the two contrasting temperament profiles were shown to be positively correlated to animal performance with "go-getters" showing shorter return to oestrous after calving and heavier calf weaning weights than "laid-back" cows. These findings are in line with Prendiville et al. (2010) who found that cows with higher production efficiency were more aggressive grazers. Pryce et al. (2005) observed that dairy animals that are lighter are capable of superior productivity within intensive pasture-based systems because of their lower maintenance requirements and higher production per unit of feed consumed. An ability to achieve large intakes of forage relative to their productivity potential should also confer an increased likelihood of survival, another integral component of optimal financial performance (Lopez-Villalobos et al., 2000) in grass-based systems. A similar observation was made more recently by O'Sullivan et al. (2019a). The inappropriateness of deriving breeding values pertinent to feed intake and feed efficiency based on records derived from a concentrate-based diet when the system of production practiced depends on performance from pasture for most of the production cycle has been raised by Lahart et al. (2020).

\section{Ability to cope with variability of grass supply}

In temperate climates, grass growth is seasonal with maximum growth observed in spring (between mid-April and end of May; 
Northern Hemisphere), a variable decrease in summer and minimal or no growth during the winter months. This is well illustrated by the grass growth profiles, presented in Figure $1 \mathrm{~A}$ and B; Ruelle et al. (2018), for the four separate regions of France and Ireland, simulated using the "Moorepark St Gilles" grass growth model. These profiles highlight the large consequences for feed availability, with an excess of grass supply often observed in spring and a deficit in winter.

As grazing systems are subjected to the external environment, animals may be exposed to unpredictable disturbances (climate, predation, disease; Mirkena et al., 2010). Animals react by initiating adaptive responses that may alter phenotype, physiology and/or behaviour. These mechanisms have been the subject of several papers (Blanc et al., 2006; Mirkena et al., 2010; Mulliniks et al., 2016) recognising the key roles of metabolic flexibility, nutrient allocation, body reserves, behavioural strategies and temperament to explain the variability in the ability to cope with external perturbations or limiting nutritional environments. In grass-based systems, a temporary reduction in animal production or alteration in functional traits may be tolerated, provided it can recover quickly when conditions become favourable again. Such rebound capacity was reported by Blanc et al. (2007) in a study where Merino ewe lambs experienced three feeding treatments from 12 to $39 \mathrm{wk}$ of age (High = ad libitum, Medium $=70 \%$ and Severe $=40 \%$ of the amounts offered in High treatment, respectively). Forty per cent of ewe lambs that experienced the severe under-nutrition were still not cycling at 9 mo of age. But after returning to ad libitum feeding, they reached puberty within a 3-wk period and could be used for mating. Such an ability to rebound is also observed for other life functions such as growth (compensatory growth in heifers, Hoch et al., 2003) or lactation as observed with daily milk yield and its interaction with paddock residency time (RocaFernandez et al., 2012).

Coupled with the seasonality in grass growth is the unstable nature of the nutritional value of grass, which changes with season, age of regrowth and phenological stages of plant growth. Leafy grass or legumes in spring are characterised by a high nutritive value in terms of energy and protein content, and also high voluntary intake. Although at this time the grass is highly palatable, the ratio between the grass energy content and the fill unit value, named energy density, can be too low to match a lactating animal's energy demand. Matching the animal demands with grass only in the spring months can, therefore, be a real challenge. With conserved grass, hay or silage not supplemented with concentrate, this situation may be intensified (Figure 2). This is particularly important for dairy cows grazing in early lactation (Peyraud \& Delagarde, 2013) or for suckling cows and ewes at the end of gestation when offered poor-quality forages indoors in winter. The challenge for the ruminant female is to maximise grass or forage intake and where deficits in energy intake exist the animal must be able to react and limit the consequences. Frequently, ewes rearing high litter sizes managed at high stocking rates coupled with the low intake capacity [of grass] are nutritionally challenged. This can have a knock-on effect on lamb growth rate and the number of days to slaughter for individual lambs
A

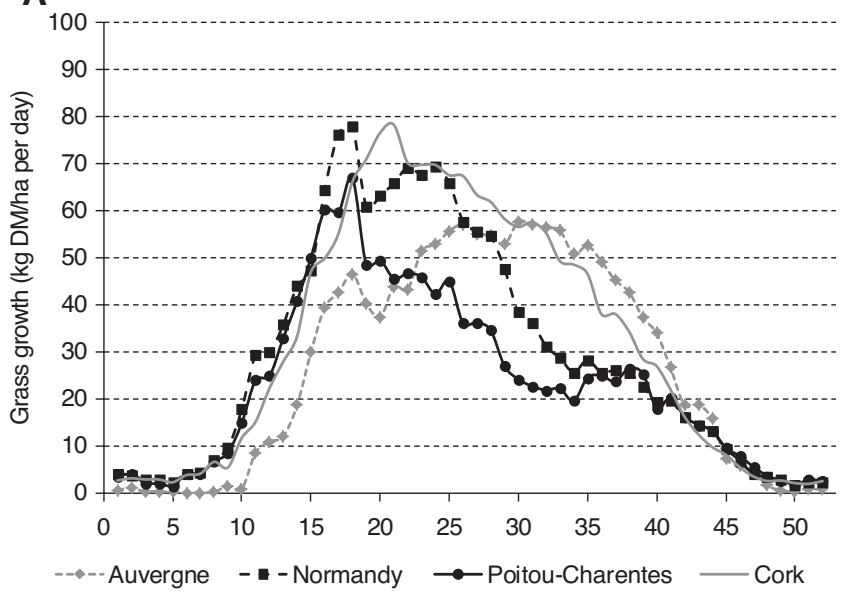

B

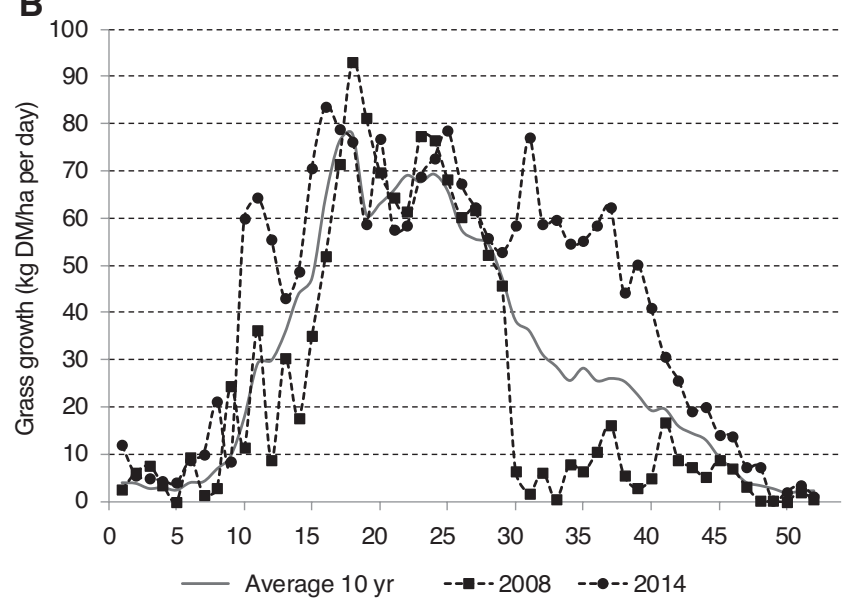

Figure 1. Annual grass growth profile according to the geographic localisation in France and Ireland (A) and the year in Normandy (B). On an average of $10 \mathrm{yr}$ (Figure 1A), the grass growth profile of a same type of pasture with the same level of $\mathrm{N}$ mineral applied differs because altitude, rain, temperature and light differ. The grass growth starts early in Ireland (Co Cork - Fermoy $-52^{\circ} 08 \mathrm{~N} / 8^{\circ} 16 \mathrm{~W}$ ), later in upland (Auvergne - Marcenat $-45^{\circ} 18^{\prime} \mathrm{N} / 2^{\circ} 49^{\prime} \mathrm{E}$ ) and is higher in summer than in Normandy - Le Pin (Lowland - 48 $44^{\prime} \mathrm{N} / 0^{\circ} 08^{\prime} \mathrm{E}$ ) or in PoitouCharentes - Lusignan (Lowland $-46^{\circ} 26^{\prime} \mathrm{N} / 0^{\circ} 07^{\prime} \mathrm{E}$ ), region with higher temperatures in summer and mainly less regular rains. Within a region, the average profile is also highly variable between years, week per week, due to the highly variable climatic conditions (Figure 1B). 


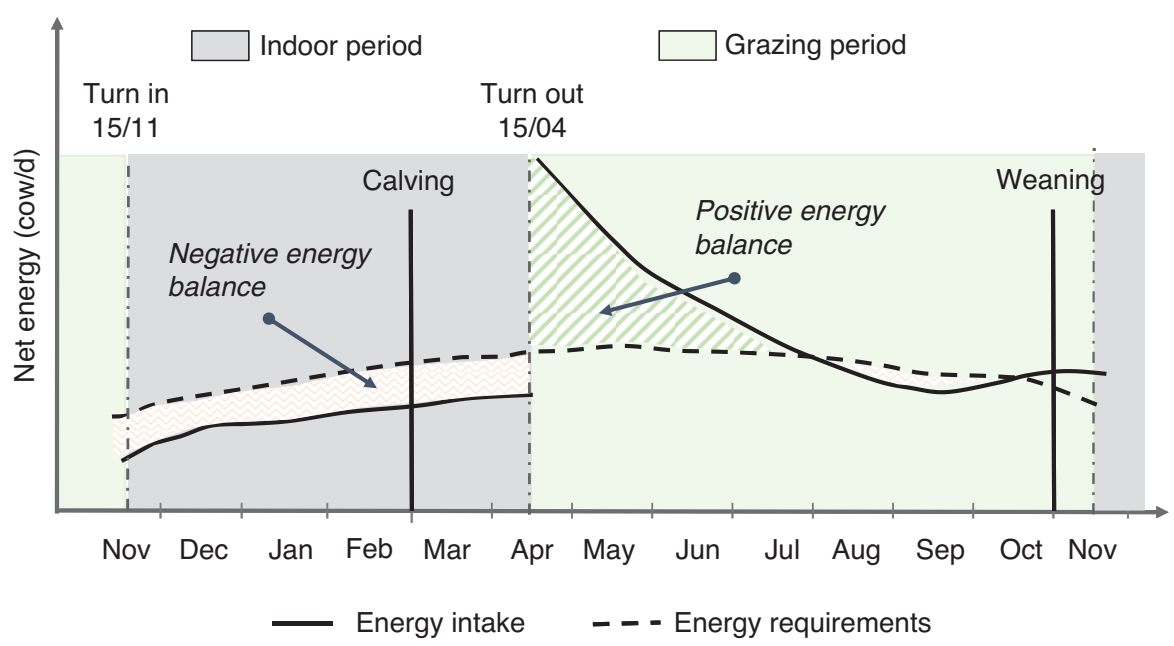

Figure 2. Changes in net energy requirements (dotted line) and energy intake (solid line) of beef cows in a winter calving system in France. Energy balance is negative during all the indoor building period because of low energy density of hay and increasing energy requirement from the end of pregnancy and early lactation. Energy balance becomes positive as cows are turned out and graze (after Institut de l'Elevage, 2015).

(Earle et al., 2017a). This imbalance between the grass energy supply and the energy demand of the lactating beef cow rarely occurs due to the relatively low milk production potential of the beef cow and milk yield demand of the often single suckled calf. Such physiological energy deficit resulting from high requirements combined with limited intake capacity have been exacerbated by genetic selection for productive traits such as milk yield in the North American Holstein (Kolver \& Muller, 1998) or high prolificacy levels in ewes (Safari et al., 2005). This has been illustrated in the INRA Le Pin (DOI: 10.15454/1.5483257052131956E12) experiment where Holstein cows are turned out at grazing and receive $3 \mathrm{~kg}$ of concentrate DM after a 9- to 11-wk early lactating period spent indoor (winter feeding period). The Holstein cows with the greatest milk yield potential had higher observed milk yields at the peak of lactation indoor and during the spring grazing period. However, they expressed a greater decline in milk yield at 6 and 12 wk post turnout (Table 1). More generally, the major adaptation to low feed availability or low nutrient density diets is lower milk production as described by Berda et al. (2007), Fulkerson et al. (2008) and previously by Veerkamp et al. (1995). This adaptation is more particularly expressed in cows of high genetic merit for milk yield (Bedere et al., 2017b). Cows that can maintain a higher body condition score may have an advantage in grass-based systems because they can draw upon body reserves if feed supply is limited (Pryce \& Harris, 2006). As described by Delaby et al. (2010), the body condition score losses, reflecting body tissue mobilisation in early lactation, are highest with Holstein cows with a higher genetic merit for milk yield compared with Normande cows.

Table 1: Effect of milk potential (evaluated with the peak of lactation) on milk and body condition score changes during the spring grazing period

\begin{tabular}{|c|c|c|c|c|c|c|c|}
\hline & \multicolumn{4}{|c|}{ Milk yield $(\mathbf{k g} / \mathrm{d})$} & \multicolumn{3}{|c|}{ Body condition score [0 to 5] } \\
\hline & $\begin{array}{c}\text { Peak of } \\
\text { lactation }\end{array}$ & $\begin{array}{l}\text { At grazing turnout } \\
\text { (lactation days) }\end{array}$ & $\begin{array}{c}6 \text { wk after } \\
\text { turnout }\end{array}$ & $\begin{array}{c}12 \text { wk after } \\
\text { turnout }\end{array}$ & $\begin{array}{l}\text { At } \\
\text { calving }\end{array}$ & $\begin{array}{c}\text { At } \\
\text { turnout }\end{array}$ & $\begin{array}{c}12 \text { wk after } \\
\text { turnout }\end{array}$ \\
\hline \multicolumn{8}{|l|}{ Primiparous } \\
\hline$>35 \mathrm{~kg}$ at peak & 39.8 & $35.9(74)$ & 30.5 & 25.3 & 3.25 & 2.50 & 2.10 \\
\hline$<35 \mathrm{~kg}$ at peak & 30.6 & $28.4(78)$ & 25.6 & 21.9 & 2.85 & 2.60 & 2.40 \\
\hline \multicolumn{8}{|l|}{ Multiparous } \\
\hline$>45 \mathrm{~kg}$ at peak & 51.0 & $45.7(60)$ & 36.1 & 30.6 & 2.85 & 2.25 & 2.00 \\
\hline$<45 \mathrm{~kg}$ at peak & 40.4 & $35.8(66)$ & 31.5 & 26.1 & 2.60 & 2.40 & 2.25 \\
\hline
\end{tabular}

Adapted from the INRA Le Pin 2006-2015 experiment. 
Similar observations were also reported by Roche et al. (2006) comparing North American or New Zealand Holstein cows with or without concentrate supplementation at grazing and by Dillon et al. (2006) within Irish experiments comparing different dairy breeds. While body condition loss in early lactation is the norm in dairy cows, the challenge is to balance the maintenance of body condition with productivity. This is best manifested via high intake capacity to minimise negative energy balance and by minimising the negative impact on subsequent rebreeding, features more associated with breeds or strains selected under grazing conditions (Horan et al., 2004; Horan et al., 2005; O'Sullivan et al., 2019a, 2019b) or with a more balanced genetic background (Cummins et al., 2012) compared with strains originating from confinement systems. A sheep study in Ireland (McGovern \& McHugh, 2017) has shown that greater body reserves mobilisation in early lactation is observed in ewes of high genetic merit for maternal traits relative to ewes of low genetic merit for maternal traits in a grass-based system. Mobilisation of body reserves in this instance is desirable as it contributes to increased milk yield and lamb output while not compromising future reproductive or production efficiency. On an annual basis, it is essential to limit the consequence of poor condition score (energy balance) on other functions such as fertility, sensitivity to disease and ultimately longevity. This has been demonstrated to be achievable where appropriate emphasis is placed on traits of economic importance within a selection objective yielding long-term gains in animal performance and profitability (O'Sullivan et al., 2020).

\section{Ability to reproduce and achieve compact parturition}

Herd/flock demand must closely align to the seasonality of grass availability (Butler, 2014; Delaby \& Horan, 2017; Earle et al., 2017a). The maximum energy demand usually occurs in the period immediately pre-parturition and during the weeks following parturition when milk production reaches its peak. Consequently, the optimal grass-based system parturition should occur in the weeks prior to high grass availability. Compact calving or lambing require a strictly managed compact breeding period and excellent fertility performance. This demands a return to cyclicity to coincide with the commencement of the breeding season and to successfully achieve pregnancy within a limited breeding period of 3 mo for cattle and 1.5 mo for ewes. In one lambing per year sheep farming systems, reproduction occurs in the postweaning period whereas in the case of both beef and dairy cows, reproduction occurs during early lactation. Ewes have a greater chance to recover body reserves prior to mating thereby increasing their ability to maximise prolificacy (i.e. litters of multiples). As prolificacy is one of the most important criteria of the lamb production system efficiency (Earle et al., 2017b), optimising litter size or prolificacy is a function of the genetic strain (Bodin et al., 2000; Dawson \& Carson, 2002) and can be supported by specific feeding practices such as flushing in low and moderate body condition score (BCS) ewes (Coop, 1966). In beef cattle when the breeding season occurs at grazing, the increase in feeding level improves the energy status of the cows thereby avoiding late resumption of luteal activity after calving, specifically in thin cows (Friggens et al., 2017). However, energy allocation priorities can differ greatly between breeds resulting in differences in the ability to cope with underfeeding environments, perform and survive. Blanc et al. (2006) reported results from a long-term experiment where Limousin cows were compared to Salers. This study clearly showed higher survival rates in Saler cows experiencing a low feeding treatment at grazing because they were able to maintain their reproductive ability compared to Limousin and thus fewer were culled. The dairy cow situation is more complicated as a consequence of the high nutrient demand for lactation in this period (Friggens et al., 2010) and impacts on a range of fertility characteristics. To obtain good reproductive performance, luteal activity has to be restored and regular, oestrus and heats should be well expressed and easy to detect, and after artificial insemination (Al), fertilisation should be effective and the embryo implantation successful to re-calve (Bedere et al., 2017a, 2017b). Although evidence of genotype $\times$ environment interaction is scarce (Washburn \& Mullen, 2014), evidence by O'Sullivan et al., (2019a, 2019b) and Horan et al. (2004) suggests that sustainable genetic improvement is contingent on compatibility with the system in which the genetics is expected to perform.

Furthermore, in order to maximise reproductive performance and lifetime production efficiency, dairy heifers must conceive at around $15 \mathrm{mo}$ and calve by $24 \mathrm{mo}$ of age (Heinrichs \& Hardgrove, 1987). In beef cattle, Forabosco et al. (2004) showed that Chianina cows calving before $35 \mathrm{mo}$ of age had a lower probability of being culled than cows calving after $35 \mathrm{mo}$ of age and superior longevity.

In seasonal production systems, the relative importance of age at puberty is greater than that in confinement and year-round calving systems. To achieve seasonal targets, an early onset of puberty is critical (Archbold et al., 2012). Breed differences exist, suggesting differences in suitability for intensive compared with less intensive pasture-based dairying and indeed beef production. The findings of Archbold et al. (2012) indicate that Jersey $\times$ Holstein-Friesian heifers are earlier maturing than Holstein-Friesian heifers, whereas continental breeds like Normande or Montbeliarde are a little bit later maturing. Larger European beef breeds were shown to grow faster to heavier mature weights but reach puberty at older ages and have lower reproductive efficiency, especially in less-favourable conditions (Morris et al., 1993). 
In countries or regions where the rain is evenly distributed across the year (40-60 mm monthly) and grass growth occurs in summer, the ideal parturition period is in spring (Figure 3). Spring turnout dates should be adapted to the start of the grass growth and will be later in northern compared with southern Europe, or in uplands compared with lowlands. For cattle, a compact calving period in spring allows peak grass growth to coincide with the lactation period. For sheep, the shorter lactation period (3 mo) allows for high stocking rates to be achieved during the highest grass growth period in the year. Moreover, during this period (i.e. spring and early summer), the grass nutritive value matches the animal nutritional requirements. An additional benefit of calving in the spring for dairy and beef cows is that the dry off period coincides with winter when grass growth is low or ceases and conserved forages can supply the lower feeding requirements. In regions with frequent drought periods in summer, two parturition periods occurring at 6-mo intervals may be optimal (Pottier et al., 2007 - Figure 3). According to the area of the grazing platform, the herd size assigned to one period can be half/half or two third/one third, respectively, in spring and autumn.

\section{Ability for maternal care and to remain healthy}

During parturition, another important robustness characteristic of dairy, beef and sheep is the ability to deliver a viable offspring. Increased dystocia at parturition (caesarian, vaginal tearing) has a negative impact on subsequent reproductive performance especially in cattle (Meijering, 1984). Levels of dystocia must also be minimised to reduce labour requirements at parturition and also to provide a favourable perception to consumers of grass-based production systems. Maternal care traits such as mothering ability or progeny suckling ability are also of importance to ensure low levels of calf or lamb mortality in all systems but especially in extensive systems (Macfarlane et al., 2010). And while these characteristics are not unique to pasture-based systems per se, it is much more likely that where intervention is required, assistance will be more available and more observant with indoor systems, particularly when compared with more extensive outdoor pasture-based systems.

In a survey (Ollion, 2015) in which dairy farmers were asked to define a robust cow, $80 \%$ of farmers answered a "cow with no problems, never sick, who doesn't need to see the veterinarian". In terms of health, three traits are specifically relevant to grass-based systems. The first key characteristic is the ability of the animal to cope with parasite burdens. Parasite burden is a major issue in pasture-based systems as, when not controlled, it can have negative effects on productivity and when anthelmintic treatments are used questions are raised in relation to its impact on the environment as well as anthelmintic resistance. At the animal level, genetic selection for reduced parasite burdens can be achieved (McHugh et al., 2014; Moreno-Romieux et al., 2017). Animals on grass-based systems are also more susceptible to the effects of inclement weather and grass nutrients imbalance (excess of nitrogen, minerals), and are therefore at greater risk of metabolic or digestive upset such as bloating, grass tetany and also, for

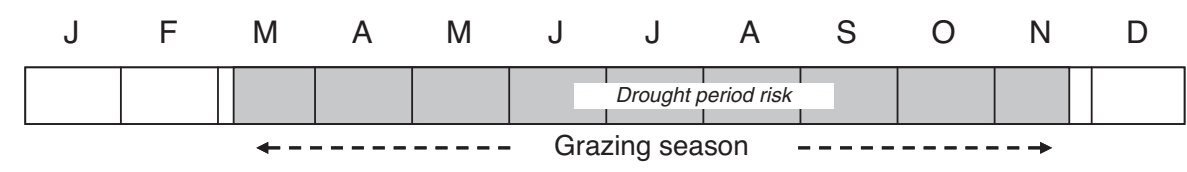

Dairy and beef cow - One calving season

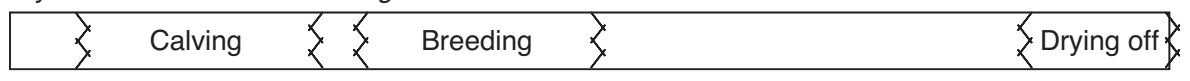

Suckling ewe - One lambing season

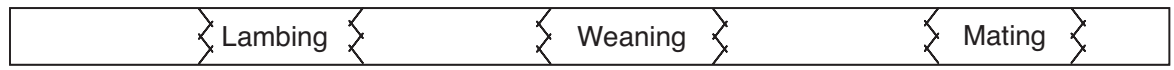

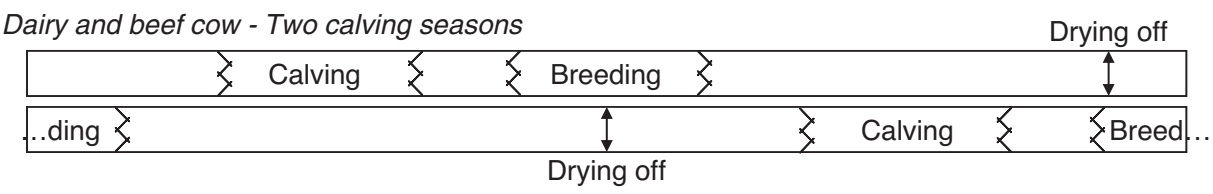

Figure 3. Grass-based system management recommendations for cattle and sheep according to the grazing season length and the risk of drought period in summer (after Pottier et al., 2007; Delaby \& Horan, 2017; Earle et al., 2017a). 
ewes, pregnancy toxaemia. Such nutritional disorders are often lethal and therefore non-occurrence is a necessity. The last major problem for grazing systems concerns feet and leg diseases. Dairy cows must walk to the milking parlour twice per day, therefore lameness is a common occurrence. In addition, lameness in sheep, often characterised by scald or footrot, is common within grass-based systems (O'Brien et al., 2017). Lameness, in either sheep or dairy cows, has a negative impact on the animal's ability to graze, thereby reducing energy intake and thus milk or growth performance, as well as reproductive performance.

\section{A robust animal must be a multi-functional animal}

Robustness is a multi-factorial trait and relies on the ability of the ruminant female to be able to assume the highlighted productive and functional expectations, to cope with constraints and be resilient. Ollion et al. (2016) performed multivariate analysis (principal component analysis) to phenotype dairy cows on the way they manage trade-offs between life functions (lactation, ability to maintain body reserves and reproductive success) when experiencing energy deficit in early lactation. The concept of dairy cow profiles developed in this study helps to describe different types of cows beyond the breed effect. This method has been applied on the INRA Le Pin experiment (Cloet et al., 2015) and four profiles with specific trade-offs have been highlighted (Figure 4). Some cows prioritise milk solids yield without a detrimental effect on reproduction (cluster 1), others are less efficient with regard to fertility without compensating in milk solids (cluster 2) or are unable to compromise (cluster 4). Clearly, cluster 3 appears to be more in accordance with compact calving grass-based systems with priority given to reproduction (pregnancy rate $=99 \%$ vs. $64 \%$ on average) and

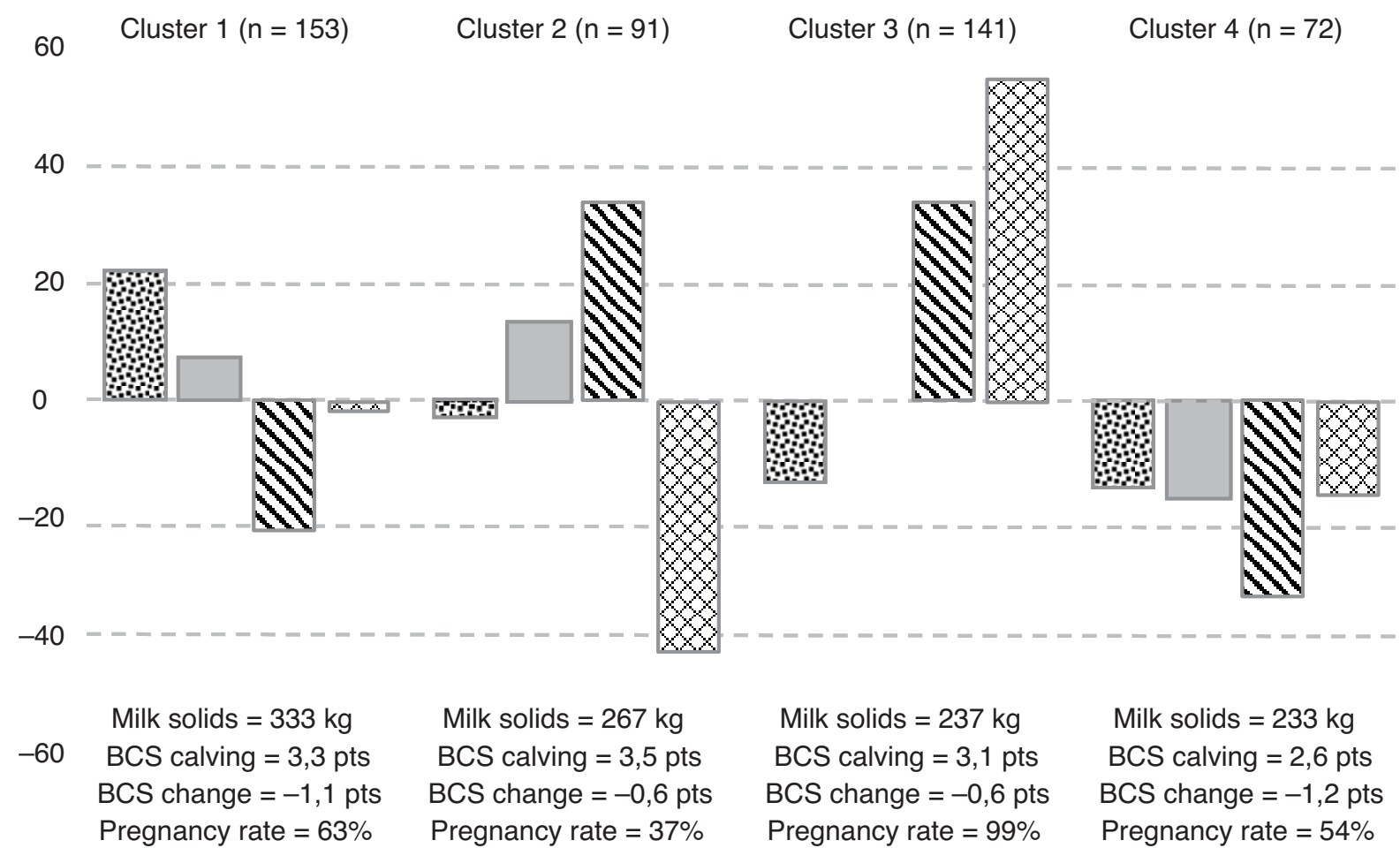

Figure 4. Expression profiles of priorities between milk solids yield, body condition score and pregnancy rate of Holstein and Normande cows. Deviations are expressed in relative proportion (\%) of the mean value observed for the 457 lactations. Clusters of lactation profiles were identified by multivariate analysis followed by clustering analysis. Values between brackets are number of lactations in each cluster. 
maintaining body condition without impairing milk solids yield. It is possible to hypothesise that such differences between profiles are associated with diversity in nutrient acquisition (forage intake capacity) and/or in nutrient allocation (Friggens et al., 2017).

Genetic improvement programmes should use a selection index that combines all the economically important traits appropriate for the local conditions and systems (Buckley et al., 2005). An excellent example of success in this regard is the Irish Economic Breeding Index (EBI) (Veerkamp et al., 2002). Both genetic trends from the national population (Figure 5) and the most recent results from a controlled experiment at Teagasc Moorepark, "Next Generation Herd" (Table 2), are illustrations of the consequence of a better agreement in the

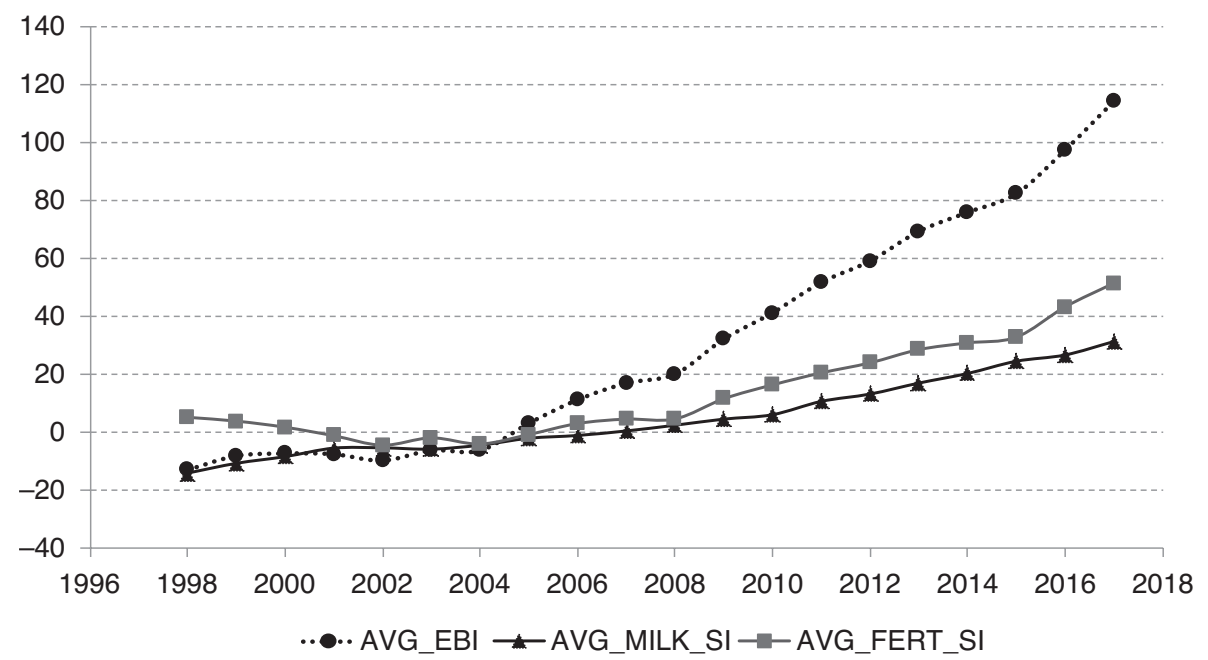

Figure 5. Rate of genetic gain in Economic Breeding Index (EBI), Milk Sub-index (MILK_SI), Fertility Sub-index (FERT-SI); € per lactation for dairy females born in Ireland between 1996 and 2017 - A. Cromie, Irish Cattle Breeding Federation, personal communication.

Table 2: Reproductive performance observed in the INRA Le Pin experiment (The cow for the system? - 2006-2019) and in the Teagasc NGH experiment (Next Generation Herd - 2013-2016) in comparison with the objective for grass-based dairy system and compact calving management (12 wk calving period)

\begin{tabular}{|c|c|c|c|c|c|c|c|}
\hline \multirow{3}{*}{$\begin{array}{l}\text { Feeding level } \\
\text { Breed }\end{array}$} & \multirow[t]{3}{*}{ Objective } & \multicolumn{4}{|c|}{ The cow for the system? (1) } & \multicolumn{2}{|c|}{ NGH (2) } \\
\hline & & \multicolumn{2}{|c|}{ High } & \multicolumn{2}{|c|}{ Low } & \multirow[b]{2}{*}{ NatAv } & \multirow[b]{2}{*}{ Elite } \\
\hline & & Holstein & Normande & Holstein & Normande & & \\
\hline Milk yield (kg) & & 8,500 & 6,100 & 6,120 & 4,650 & 5,820 & 5,610 \\
\hline BCS at calving (pts [0 to 5$]$ ) & & 2.85 & 3.45 & 2.70 & 3.10 & 3.00 & 3.25 \\
\hline BCS losses (pts [0 to 5]) & 0.50 & -1.00 & -0.65 & -1.20 & -0.80 & -0.40 & -0.40 \\
\hline Interval calving - first ovulation (d) & $25-30$ & 39 & 32 & 36 & 29 & 27 & 25 \\
\hline Normal cyclicity profile rate (\%) & 80 & 53 & 70 & 46 & 77 & 1 & 1 \\
\hline First $\mathrm{Al}$ in-calf rate $(\%)$ & 60 & 36 & 45 & 34 & 43 & 45 & 60 \\
\hline 6 wk in-calf rate $(\%)$ & 70 & 39 & 50 & 40 & 52 & 58 & 73 \\
\hline 13 wk in-calf rate (\%) & 90 & 59 & 74 & 60 & 71 & 83 & 93 \\
\hline
\end{tabular}

(1) High: In winter (100 d), early in lactation, total mixed ration with maize silage, dehydrated alfalfa and concentrate, ad libitum. At grazing (180 d), 0.35 ha per cow, $4 \mathrm{~kg}$ concentrate and $5 \mathrm{~kg}$ maize silage from July. In autumn ( $85 \mathrm{~d}), 5 \mathrm{~kg}$ maize silage, $4 \mathrm{~kg}$ concentrate and grass silage ad libitum. Low: In winter (100 d), early in lactation, total mixed ration with grass silage and big bale haylage, ad libitum. At grazing (180 d), 0.55 ha per cow. In autumn ( 85 d), grass silage ad libitum. No concentrate. (2) Two genotypes based on Ireland's dairy selection index, the Economic Breeding Index (EBI): NatAv ( $n=45$ annually) representing national average based on EBI and Elite ( $n=90$ annually) representing the top $1 \%$.

$\mathrm{Al}=$ artificial insemination; $\mathrm{BCS}=$ body condition score. 
selection criteria and producer goals (Buckley et al., 2017). Experimental evidence from studies in beef and sheep also indicate that selection of females based on their genetic merit for maternal type traits may result in the selection of a more robust female for grass-based systems (McCabe et al., 2016; McGovern \& McHugh, 2017). A "better balance" may also be obtained by crossbreeding (Buckley et al., 2014; Dezetter et al., 2015; Coffey et al., 2016) due to a combination of both breed complementarity and heterosis.

This concept of a well-balanced animal is highlighted by grassland farmers in response to an open multi-answer survey undertaken by Ollion (2015) and presented by Ollion et al. (2018). The question was "What is a robust cow to you?" The traits most often cited are linked with the pasture-based system requirements. The first trait cited by $80 \%$ of the surveyed farmers was good health (never sick, no veterinary care required) followed by morphology (64\%; solid legs, able to go grazing, good udder). The third trait $(33 \%)$ concerned reproductive function with a desire for one calf every year. Intake capacity, milk yield and temperament completed the list, cited by $18-20 \%$ of the farmers. Apart from functional, productive or behavioural traits, dairy farmers also characterised a robust cow through integrative characteristics or properties. "Longevity" was mentioned by $50 \%$ of the farmers followed by "invisible" (36\%) and "ability to adapt" $(33 \%)$. Longevity is also considered to be the most important trait in pasture-fed beef cattle (Forabosco et al., 2004) as the cow has to last long enough in the herd (more than five or six calves) to generate a solid return on investment (Forabosco et al., 2005). In the "Pasture Project" (http://pastureproject. org/wp-content/uploads/2016/02/Grass-fed-genetics.pdf), longevity is clearly associated to more elementary traits which are adaptability to the environment, fertility, soundness of feet, legs, eyes and udders. If an animal is lacking in any of these traits, it has a reduced chance of longevity in the herd, failing to breed or rebreed, or failing to maintain adequate body condition, and therefore not remaining in the herd for very long.

Transparency means that the animal does what it has to do without playing on the farmer's mental work load. This last expression (The better females are those you never hear about) was also reported by Brochard et al. (2016). Of course, such cow characteristics are not specific to grassbased systems. Most of them have already been outlined in previous studies dedicated to profiling the ideal cow for the future (Berry, 2015) or defining traits for robustness in dairy cows (Calus et al., 2013; Roche et al., 2018). However, what appears to be specific is the importance farmers give to each of these characteristics. The priorities clearly differ according to environments and objectives of production systems and are taken into account when revising breeding selection indices. Cole \& VanRaden (2018) compared traits included in total merit indices of dairy cows in 16 different countries and clearly showed that groups of traits are common such as yield (milk volume, fat and protein yield), longevity (productive life, survival), fertility (days open, 6-wk in-calf rate), health, calving traits, milking traits and conformation (udder, feet, leg score). However, the respective weights of these traits may differ largely between countries, some of them giving more than $60 \%$ to yield (Israel, Japan, Cheese Merit index in the United States) and others less than 40\% (France, Ireland, United Kingdom). When production systems are quite different within a country, breeding organisms can propose variants. In the United States, the grazing merit index differs from the total performance index through a lower weight given to conformation and body size traits in favour of a higher weight given to fertility traits (Cole \& VanRaden, 2018).

\section{Conclusion}

Some robustness traits highlighted in this synthesis are common to all systems. But due to specificities of pasturebased systems, the hierarchy and the intensity of requirements are different. For [semi] intensive pasture-based systems, robustness can be defined under three broad characteristics: 1) match high milk or growth performance to high forage intake capacity; 2) ensure high fertility (cattle) and prolificacy (sheep) and the delivery of offspring without assistance; and 3) remain healthy. These three main objectives challenge breeding and genetic research to define and to be able to evaluate the best parameters to select future generations of ruminant livestock.

\section{References}

Archbold, H., Shalloo, L., Kennedy, E., Pierce, K.M. and Buckley, F. 2012. Influence of age, body weight and body condition score before mating start date on the pubertal rate of maiden HolsteinFriesian heifers and implications for subsequent cow performance and profitability. Animal 6: 1143-1151.

Bedere, N., Disenhaus, C., Ducrocq, V., Leurent-Colette, S. and Delaby, L. 2017a. Ability of dairy cows to be inseminated according to breed and genetic merit for production traits under contrasting pasture-based feeding systems. Animal 11: 826-835.

Bedere, N., Disenhaus, C., Ducrocq, V., Leurent-Colette, S. and Delaby, L. 2017b. Ability of dairy cows to ensure pregnancy according to breed and genetic merit for production traits under contrasted pasture-based systems. Journal of Dairy Science 100: 2812-2827.

Berda, B., Ouweltjes, W., Sebek, L.B.J., Windig, J.J., Veerkamp, R.F. 2007. Effects of genotype by environment interactions on milk yield, energy balance and protein balance. Journal of Dairy Science 90: 219-228. 
Berry, D.P. 2015. Breeding the dairy cow of the future: what do we need? Animal Production Science 55: 823-837.

Blanc, F., Bocquier, F., Agabriel, J., D'Hour, P. and Chilliard, Y. 2006. Adaptative abilities of the females and sustainability of ruminant livestock systems: a review. Animal Research 55: 489-510.

Blanc, F., Fabre, D., Bocquier, F., Canepa, S., Delavaud, C., Caraty, A., Chilliard, Y. and Debus, N. 2007. Effect of a post-weaning restricted nutrition on the initiation of puberty and the reproductive performances of early bred Merino ewe-lambs. Options Méditerranéennes, Série A 74: 387-393.

Bodin, L., Elsen, J.M., Benoit, M., SanCristobal, M. and Chevalet, C. 2000. Selection for prolificacy: new prospects for an everinteresting objective. In: "Analysis and Definition of the Objectives in Genetic Improvement Programmes in Sheep and Goats. An Economic Approach to increase their Profitability," (ed. D. Gabiña), Zaragoza, CIHEAM, pages 117-120.

Brochard, M., Delaby, L., Dumont, B., Ezanno, P., Foucras, G, Frappat, B., Gonzales-Garcia, E., Hazard, D., Moreno, C. and Phocas, F. 2016. Outils et leviers pour favoriser le développement d'une génétique adaptée aux enjeux de l'agro-écologie pour les élevages de ruminants. Rencontres Recherches Ruminants 23: 137-140.

Buckley, F., Lopez-Villalobos, N. and Heins, B.J. 2014. Crossbreeding: implications for dairy cow fertility and survival. Animal 8: 122-133.

Buckley, F., Holmes, C. and Keane, G. 2005. Genetic characteristics required in dairy and beef cattle for temperate grazing systems. XX International Grassland Congress, Cork Satellite Meeting, July 3-5, pages 61-75.

Buckley, F., O'Sullivan, M., McParland, S., Lahart, B. and Shalloo, L. 2017. Teagasc's Next Generation dairy herd - proofing the EBI. In Irish Dairying - Resilient Technologies, Moorepark'17 Open day 4th July, pages 90-91. Available online: https://www.teagasc. ie/media/website/publications/2017/Teagasc-Moorepark2017Booklet.pdf.

Butler, S. 2014. Nutritional management to optimize fertility of dairy cows in pasture-based systems. Animal 8: 15-26.

Calus, M.P.L., Berry, D.P., Banos, G., de Haas, Y. and Veerkamp, R.F. 2013. Genomic selection: the option for new robustness traits? Advances in Animal Biosciences 4: 618-662.

Cardoso, C.S., Hötzel, M.J., Weary, D.M., Robbins, J.A. and von Keyserlingk, M.A.G. 2016. Imagining the ideal dairy farm. Journal of Dairy Science 99: 1663-1671.

Cloet, E., Blanc, F., Ollion, E. and Delaby, L. 2015. La robustesse des vaches laitières: Une approche basée sur les compromis entre fonctions biologiques et perspectives de valorisation dans les schémas de sélection génétique, Mémoire de fin d'études, ISA Lille, 80 pages.

Coffey, E.L., Horan, B., Evans, R.D. and Berry, D.P. 2016. Milk production and fertility performance of Holstein, Friesian, and Jersey purebred cows and their respective crosses in seasonalcalving commercial farms. Journal of Dairy Science 99: 5681-5689.
Cole, J.B. and VanRaden, P.M. 2018. Symposium review: Possibilities in an age of genomics: The future of selection indices. Journal of Dairy Science 101: 3686-3701.

Coop, I.E. 1966. Effect of flushing on reproductive performance of ewes. Journal of Agricultural Science 67: 305-323.

Cummins, S.B., Lonergan, P., Evans, A.C., Berry, D.P., Evans, R.D. and Butler, S.T. 2012. Genetic merit for fertility traits in Holstein cows: I. Production characteristics and reproductive efficiency in a pasture-based system. Journal of Dairy Science 95: 1310-1322.

Dawson, L.E.R and Carson, A.F. 2002. Effects of crossbred ewe genotype and ram genotype on ewe prolificacy, lamb viability and lamb output in the lowland sector. Journal of Agricultural Science, Cambridge 139: 169-181.

Delaby, L. and Horan, B. 2017. Improved efficiency in temperate grass based dairy systems. Proceedings of the $54^{a}$ Reunião Anual da Sociedade Brasileira de Zootecnia, 24 a 28 de Julho de 2017 Foz do Iguaçu - Brasil, pages 133-145.

Delaby, L., Horan, B., O'Donovan, M., Gallard, Y. and Peyraud, J.L. 2010. Are high genetic merit dairy cows compatible with low input grazing system? Grassland Science in Europe 15: 928-930.

Delagarde, R., Prache, S., D'Hour, P. and Petit, M. 2001. Ingestion de l'herbe par les ruminants au pâturage. Fourrages 166: 189-212.

Dezetter, C., Leclerc, H., Mattalia, S., Barbat, A., Boichard, D. and Ducrocq, V. 2015. Inbreeding and crossbreeding parameters for production and fertility traits in Holstein, Montbéliarde, and Normande cows. Journal of Dairy Science 98: 4904-4913.

Dillon, P. 2005. Achieving high DM intake from pasture with grazing dairy cows. In: "Fresh Herbage for Dairy Cattle: The Key to a Sustainable Food Chain", (eds. J. Dijkstra, S. Taminga, R.T. Bogers and A. Elgersma), Proceedings of the Frontis Workshop on fresh herbage for dairy cattle. Wageningen, The Netherlands: Wageningen Agricultural University, pages 1-26.

Dillon, P., Berry, D.P., Evans, R.D., Buckley, F. and Horan, B. 2006. Consequences of genetic selection for increased milk production in European seasonal pasture based systems of milk production. Livestock Science 99: 141-158.

Earle, E., McHugh, N., Boland, T. and Creighton, P. 2017a. Effect of ewe prolificacy potential and stocking rate on ewe and lamb performance in a grass-based lamb production system. Journal of Animal Science 95: 154-164.

Earle, E., Boland, T., McHugh, N. and Creighton, P. 2017b. Measures of lamb production efficiency in a temperate grass-based system differing in ewe prolificacy potential and stocking rate. Journal of Animal Science 95: 3504-3512.

Forabosco, F., Groen, A.E., Bozzi, R., Van Arendonk, J.A.M., Filippini, F., Boettcher, P. and Bijma, P. 2004. Phenotypic relationships between longevity, type traits, and production in Chianina beef cattle. Journal of Animal Science 82: 1572-1580.

Forabosco, F., Bozzi, R., Boettcher, P., Filippini, F., Bijma, P. and Van Arendonk, J.A.M. 2005. Relationship between profitability and type traits and derivation of economic values for reproduction and 
survival traits in Chianina beef cows. Journal of Animal Science 83: 2043-2051.

Friggens, N.C., Disenhaus, C. and Petit, H.V. 2010. Nutritional subfertility in the dairy cow: towards improved reproductive management through a better biological understanding. Animal 4: 1197-1213.

Friggens, N.C., Blanc, F., Berry, D.P. and Puillet, L. 2017. Review: deciphering animal robustness. A synthesis to facilitate its use in livestock breeding and management. Animal 11: 2237-2251.

Fulkerson, W.J., Davison, T.M., Garcia, S.C., Hough, G., Goddard, M.E., Dobos, R. and Blockey, M. 2008. Holstein-Friesian dairy cows under a predominantly grazing system: interaction between genotype and environment. Journal of Dairy Science 91: 826-839.

Goodman, L.E., Cibils, A.F., Wesley, R.L., Mulliniks, J.T., Petersen, M.K., Scholljegerdes, E.J. and Cox, S.H. 2016. Temperament affects rangeland use patterns and reproductive performance of beef cows. Rangelands 38: 292-296.

Heinrichs, A. and Hargrove, G. 1987. Standards of weight and height for Holstein heifers. Journal of Dairy Science 70: 653-660.

Hoch, T., Begon, C., Cassar-Malek, I., Picard, B. and SavaryAuzeloux, I. 2003. Mécanismes et conséquences de la croissance compensatrice chez les ruminants. INRA Productions Animales 16: 49-59.

Horan, B., Mee, J.F., Rath, M., Connor, P.O. and Dillon, P. 2004. The effect of strain of Holstein-Friesian cow and feeding system on reproductive performance in seasonal-calving milk production systems. Animal Science 79: 453-467.

Horan, B., Dillon, P., Faverdin, P., Delaby, L., Buckley, F. and Rath, M. 2005. The interaction of strain of Holstein-Friesian cows and pasture-based feed systems on milk yield, body weight and body condition score. Journal of Dairy Science 88: 1231-1243.

Horan, B., Faverdin, P., Delaby, L., Rath, M. and Dillon, P. 2006. The effect of strain of Holstein-Friesian dairy cow and pasture-based system on grass intake and milk production. Animal Science $\mathbf{8 2}$ : 435-444.

Huguenin-Elie, O., Delaby, L., Le Clec'h, S., Moreno, G.M., Teixeira, R.F.M. and Schneider, M.K. 2018. Optimising ecosystem services provided by grassland system. Grassland Science in Europe 23: 520-533.

Institut de l'Elevage, 2015. "Guide de l'alimentation du troupeau bovin allaitant. Vaches, veaux et génisses de renouvellement". Ed. Institut de l'élevage, Paris, 340 pages.

Kennedy, J., Dillon, P., Delaby, L., Faverdin, P., Stakelum, G. and Rath, M. 2003. Effect of genetic merit and concentrate supplementation on grass intake and milk production with Holstein Friesian dairy cows. Journal of Dairy Science 86: 610-621.

Kolver, E.S. and Muller, L.D. 1998. Performance and nutrient intake of high producing Holstein cows consuming pasture or a total mixed ration. Journal of Dairy Science 81: 1403-1411.

Lahart, B., Prendiville, R., Buckley, F., Kennedy, E., Conroy, S.B., Boland, T.M. and McGee, M. 2020. The repeatability of feed intake and feed efficiency in beef cattle offered high-concentrate, grass silage and pasture-based diets. Animal 14: 2288-2297.
Lopez-Villalobos, N., Garrick, D.J., Blair, H.T and Holmes, C.W. 2000. Possible effects of 20 five years of selection and crossbreeding on the genetic merit and productivity of New Zealand dairy cattle. Journal of Dairy Science 83: 154-163.

Macfarlane, J.M., Matheson, S.M. and Dwyer, C.M. 2010. Genetic parameters for birth difficulty, lamb vigour and lamb suckling ability in Suffolk sheep. Animal Welfare 19: 99-105.

Meijering, A. 1984. Dystocia and stillbirth in cattle: a review of causes, relations and implications. Livestock Production Science 11: 143-177.

McCabe, S., Mc Hugh, N., O'Connell, N.E. and Prendiville, R. 2016. Comparative maternal performance of high and low replacement index beef cows. Proceedings of the British Society of Animal Science, 07-April-2016, page 93.

McCarthy, B., Delaby, L., Pierce, K.M., Journot, F. and Horan, B. 2011. Meta-analysis of the impact of stocking rate on the productivity of pasture-based milk production systems. Animal 5: 784-794.

McGovern, F. and McHugh, N. 2017. An Irish New Zealand Animal Comparison - The INZAC Flock. Teagasc Sheep Open Day. Teagasc, pages 66-70.

McHugh, N., Potterton, S., Wall, E. and Pabiou, T. 2014. Genetics of sheep health traits. In "10th World Congress on Genetics Applied to Livestock Production", Vancouver, Canada, page 896.

Mirkena, T., Duguma, G., Haile, A., Tibbo, M., Okeyo, A.M., Wurzinger, M. and Sölkner, J. 2010. Genetics of adaptation in domestic farm animals: a review. Livestock Science 132: 1-12.

Moreno-Romieux, C., Sallé, G., Jacquiet, P., Blanchard, A., Chylinski, C., Cabaret, J., François, S D., Saccareau, M., Astruc, J.M., Bambou, J.C. and Mandonnet, N. 2017. La résistance génétique aux infections par les nématodes gastro-intestinaux chez les petits ruminants: un enjeu de durabilité pour les productions à l'herbe. INRA, Productions Animales, 301: 47-56.

Morris, C.A., Baker, R.C., Hickey, S.M., Johnson, D.L., Cullery, N.G. and Wilson, J.A. 1993. Evidence of genotype by environment interaction for reproductive and maternal traits. Animal Production 56: 69-83.

Mulliniks, J.T., Cope, E.R., McFarlane, Z.D., Hobbs, J.D. and Waterman, R.C. 2016. Drivers of grazing livestock efficiency: how physiology, metabolism, experience and adaptability influence productivity. Journal of Animal Science 94: 111-119.

O'Brien, A.C., McHugh, N., Wall, E., Pabiou, T., McDermott, K., Randles, S., Fair, S. and Berry, D.P. 2017. Genetic parameters for lameness, mastitis and dagginess in a multi-breed sheep population. Animal 11: 911-919.

O'Donovan, M. and Delaby, L. 2016. Grazed grass in the dairy cow diet - how this can be achieved better! Grassland Science in Europe 21: 350-365.

O'Sullivan, M., Horan, B., Pierce, K.M., McParland, S., O'Sullivan, K. and Buckley, F. 2019a. Milk production of Holstein-Friesian cows of divergent Economic Breeding Index evaluated under seasonal pasture-based management. Journal of Dairy Science 102: 2560-2577. 
O'Sullivan, M., Dillon, P., O'Sullivan, K., Pierce, K.M., Galvin, N., Egan, M. and Buckley, F. 2019b. Intake, efficiency, and feeding behavior characteristics of Holstein-Friesian cows of divergent Economic Breeding Index evaluated under contrasting pasture-based feeding treatments. Journal of Dairy Science 102: 8234-8246.

O'Sullivan, M., Shalloo, L., Pierce, K.M. and Buckley, F. 2020. Economic assessment of Holstein-Friesian dairy cows of divergent Economic Breeding Index evaluated under seasonal calving pasture-based management. Journal of Dairy Science 103: 10311-10320.

Ollion, E. 2015. Evaluation de la robustesse des vaches laitières: entre aptitudes biologiques des animaux et stratégies de conduite des éleveurs. PhD thesis, Clermont Ferrand, France, page 254. Available online: https://tel.archives-ouvertes.fr/tel-01312209/ document.

Ollion, E., Ingrand, S., Delaby, L., Trommenschlager, J.M., ColetteLeurent, S. and Blanc, F. 2016. Assessing the diversity of tradeoffs between life functions in early lactation cows. Livestock Science 183: 98-107.

Ollion, E., Cloet, E. Brives, H. and Magne, M.A. 2018. Suitable cows for grass-based systems: what stakeholders do? Grassland Science in Europe 22: 937-939.

Penno, J.W. 1998. Principles of profitable dairying. Proceedings of the Ruakura farmers conference 50: 1-14.

Pérez-Prieto, L.A. and Delagarde, R. 2013. Meta-analysis of the effect of pasture allowance on pasture intake, milk production, and grazing behavior of dairy cows grazing temperate grasslands. Journal of Dairy Science 96: 6671-6689.

Peyraud, J.L. and Delagarde, R. 2013. Managing variations in dairy cow nutrient supply under grazing. Animal 7: 57-67.

Pottier, E., Delaby, L. and Agabriel, J. 2007. Adaptations de la conduite des troupeaux bovins et ovins aux risques de sécheresse. Fourrages 191: 267-284.

Prendiville, R., Lewis, E., Pierce, K.M. and Buckley, F. 2010. Comparative grazing behaviour of lactating Holstein-Friesian, Jersey and Jersey $\times$ Holstein-Friesian cows and it association with intake capacity and production efficiency. Journal of Dairy Science 93: 764-774.

Pryce, J.E. and Harris, B.L. 2006. Genetics of body condition score in New Zealand dairy cows. Journal of Dairy Science 89: 4424-4432.

Pryce, J.E., Harris, B.L., Montgomerie, W.A., Jackson, R, MacDonald, K.A., Glassey, C.B., Thorrold, B.S. and Holmes, C.W. 2005.
Comparing feed allowances to inferred energy intake using data from a dairy grazing farm trial. Proceedings NZ Society of Animal Production 65: 225-230.

Roca-Fernandez, A.I., Gonzales-Rodriguez, A., Leurent, S., LopezMosquera, M.E., Gallard, Y. and Delaby, L. 2012. Milk performance of two cow breeds at two levels of supplementation in long residence time grazing paddocks. Grassland Science in Europe 17: 267-269.

Roche, J.R., Berry, D.P. and Kolver, E.S. 2006. Holstein-Friesian strain and feed effects on milk production, body weight and body condition score profiles in grazing dairy cows. Journal of Dairy Science 89: 3532-3543.

Roche, J.R., Berry, D.P., Delaby, L., Dillon, P.G., Horan, B., Macdonald K.A. and Neal, M. 2018. Review: new considerations to refine breeding objectives of dairy cows for increasing robustness and sustainability of grass-based milk production systems. Animal 12: 350-362.

Ruelle, E., Hennessy, D. and Delaby, L. 2018. Development of the Moorepark-St Gilles grass growth model MoSt GG model: a predictive model for grass growth in pasture based systems. European Journal of Agronomy 99: 80-91.

Safari, E., Fogarty, N.M. and Gilmour, A.R. 2005. A review of genetic parameter estimates for wool, growth, meat and reproduction traits in sheep. Livestock Production Science 92: 271-289.

Stakelum, G. and Dillon, P. 2003. The effect of concentrate type and sward characteristics on herbage intake, diet composition and grazing behavior of dairy cows. Irish Journal of Agriculture and Food Research 42: 55-70.

Veerkamp, R., Simm G. and Oldham J.D. 1995. Genotype by environment interactions: Experience from Langhill. In "Breeding and Feeding the High Genetic Merit Dairy Cow", Occasional Publication $\mathrm{N}^{\circ} 19$, BSAS, pages $59-66$.

Veerkamp, R.F., Dillon, P., Kelly, E., Cromie, A.R. and Groen, A.F. 2002. Dairy cattle breeding objectives combining yield, survival and calving interval for pasture-based systems in Ireland under different milk quota scenarios. Livestock Production Science 76: 137-151.

Veerkamp, R., Kaal, L., De Haas, Y. and Oldham, J. 2013. Breeding for robust cows that produce healthier milk: RobustMilk. Advances in Animal Biosciences 43: 594-599.

Washburn, S.P. and Mullen, K.A.E. 2014. Invited review: genetic considerations for various pasture-based dairy systems. Journal of Dairy Science 97: 5923-5938. 